\section{Europe pares down double patents on breast-cancer gene}

\section{Alison Abbott, Munich}

In battles worthy of a TV court drama, the European Patent Office (EPO) has slashed the scope of two patents on the breast-cancer gene BRCA1. Mutations in this gene predispose women to some hereditary forms of breast cancer.

The outcome can be seen as a victory for those who use the gene to diagnose cancers, but the rulings also raise an ethical conundrum. The gene's most common mutation - frequent in a single group, the Ashkenazi Jews - remains protected by patents; 33 others do not.

In the 1990s, several research groups raced against each other to find the sequence of BRCA1. Myriad Genetics of Salt Lake City in Utah rushed to file a flurry of patents - three of them in Europe - based on the sequence. Myriad required all tests for the gene to be carried out in its labs in Salt Lake City, prompting opposition from enraged clinical researchers in Europe.

Last May, the EPO revoked in its entirety one of Myriad's three patents. In its rush to secure rights, Myriad had filed its sequence of the normal gene with the US patent office in a rough form. It updated the filed sequence regularly, but the EPO ruled that the correct sequence had been filed only after other scientists had deposited the correct sequence in a public database, making it invalid for patenting (see Nature 429, 329; 2004).

Myriad has filed an appeal against this decision. It has also transferred ownership of the European patents to the University of Utah, which is now handling opposition to the other two patents, one covering the gene product itself and the other covering specific mutations.

On 20 January the EPO ruled that the patent on the gene product - whose scope originally included any probe, or nucleotide sequence, that can recognize the gene - should be restricted to just one probe. This probe corresponds to a part of the gene whose sequence was completely correct in an early filing.

A ruling on the third patent came on 25 January. This patent originally covered 34 known mutations of $B R C A 1$, but had been restricted, during negotiations in advance of the hearing, to a single mutation - the most common one, which occurs with highest frequency in Ashkenazi Jews. The hearing supported the patent, overruling objections that finding a common mutation in a known gene is not truly inventive.

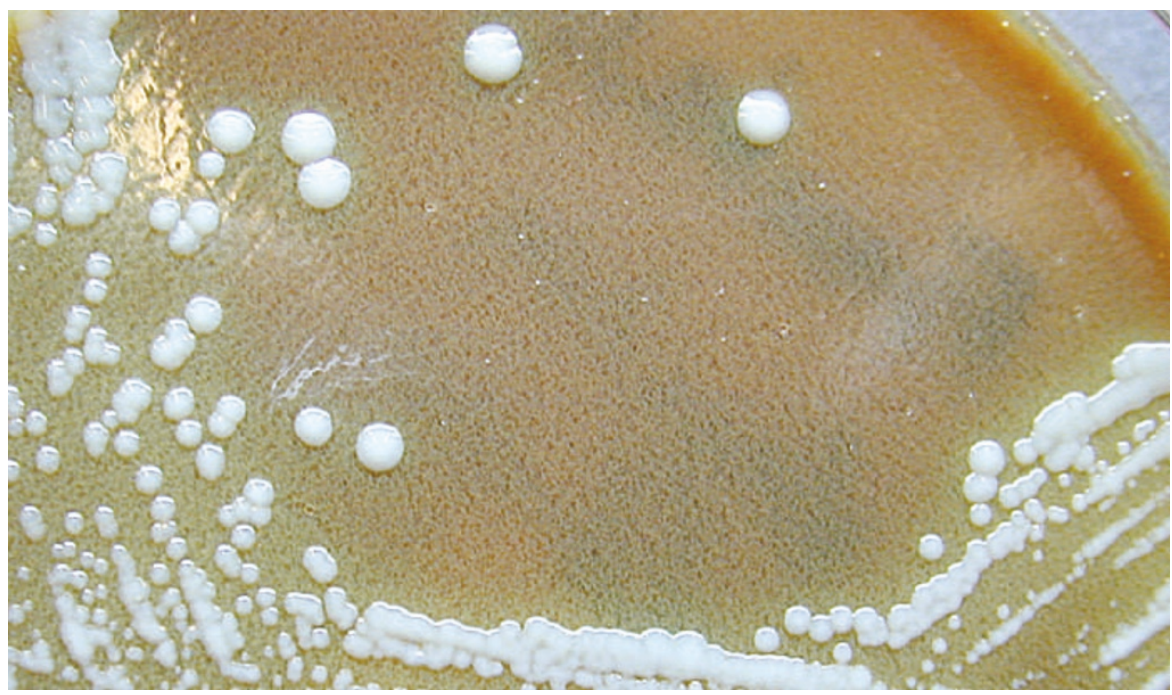

No one is sure how an active strain of tularaemia bacteria managed to infect university lab workers.

\title{
Infection scare inflames fight against biodefence network
}

Rex Dalton, San Diego

The accidental infection of three Boston University researchers with dangerous bacteria is raising questions about the US expansion of biodefence labs.

Massachusetts-based Boston University has been chosen by the National Institutes of Health to host one of two major research and containment centres for deadly pathogens. The university is planning to build a National Biocontainment Laboratory in a well populated area of south Boston, much to the dismay of residents. The US\$128-million facility will be part of a system of labs being developed across the United States.

But last year, experiments by researchers at Boston University's medical campus caused three of them to get tularaemia infections. "This is symbolic of what can happen," says Boston University epidemiologist David Ozonoff, who switched last year from supporting the biodefence lab to opposing it.

The researchers thought they were handling the tularaemia bacterium, which could be used for bioterrorism, in its deactivated form. In May, two of the researchers became ill with respiratory infections. No one suspected the cause until October, after a third researcher had sickened. The US Centers for Disease Control and Prevention, based in Atlanta, Georgia, was notified about the cases in mid-November.

Since then, the patients have recovered. But the handling of the case has caused outrage and stirred opposition to the biodefence lab. The university delayed reporting the incidents to state health authorities by 12 days, although state law requires that such cases be reported within 24 hours. And the university — along with city, state and federal officials
— did not publicly disclose the infections until last week. This meant the issue was not discussed last autumn during the planning process for the biodefence lab.

"If there was any risk outside these three infected people, we would have made a general announcement in a heartbeat," says Thomas Moore, acting provost of Boston University's medical campus, pointing out that tularaemia cannot be passed from person to person. He says that announcements were delayed until after internal investigations, and adds that the infections were not considered relevant to public debate over the biodefence lab, because that will have better containment facilities.

In the aftermath of the incident, Boston University's chief of infectious disease at the time, Peter Rice, was removed from his position. And Boston health officials say they are preparing an education campaign for lab personnel, to ensure that safety regulations are followed. It is thought that the researchers who became ill may have been working without the required fume hood.

But details of the case continue to raise questions. For instance, Paul Mead, an epidemiologist at the Centers for Disease Control and Prevention, says his agency has been unable to determine how and where the non-infectious sample became contaminated with a wild, infectious strain. "This is a bit of a freak event," says Mead. Perhaps tularaemia-contaminated rabbit blood was used as a culture medium, he says. Genetic testing of material may pin down the source.

Officials at the National Institute of Allergy and Infectious Diseases, which will fund the Boston biodefence lab and the national system, declined to comment on the incident as an investigation is still under way. 